\title{
Gerakan literasi sekolah untuk meningkatkan budaya baca di SMA Negeri 1 Geger
}

\author{
Sri Agustin ${ }^{1}$, Bambang Eko Hari Cahyono² \\ 1,2) Universitas PGRI Madiun, Jl. Setibudi No. 85 Madiun, Indonesia \\ e-mail: ${ }^{1)}$ agustinsri.19@gmail.com; ${ }^{2}$ behc@unipma.ac.id
}

\begin{abstract}
Abstrak
Penelitian ini bertujuan untuk mendeskripsikan Gerakan Literasi Sekolah dalam meningkatkan budaya baca di SMA Negeri 1 Geger, Kabupaten Madiun. Berdasarkan permasalahan yang telah ditetapkan, penelitian ini merupakan penelitian deskriptif kualitatif. Subyek penelitian adalah wakil kepala sarana prasarana, tim literasi, staf perpustakaan, dan dua orang siswa kelas XI (putra dan putri). Teknik yang digunakan dalam pengumpulan data adalah wawancara, observasi lapangan, dan analisis dokumen. Data yang terkumpul dianalisis dengan menggunakan analisis interaktif. Berdasarkan analisis data dapat disimpulkan bahwa penerapan Gerakan Literasi Sekolah (GLS) sudah mulai menunjukkan gaungnya. Beberapa pihak yang merupakan komponen penting dari gerakan literasi ini, secara pelan tetapi pasti mulai menunjukkan kepeduliannya. Pelaksanaan GLS di lapangan, dilakukan pada pagi hari sebelum jam pertama atau sebelum memulai kegiatan belajar mengajar. Buku Jurnal Baca disediakan di setiap kelas, untuk memantau perkembangan siswa dalam kegiatan literasi.
\end{abstract}

Kata kunci: Literasi; Budaya Baca

\section{School literacy movement to increase students' reading culture of SMA Negeri 1 Geger}

\begin{abstract}
This research aims to describe Gerakan Literasi Sekolah (School Literacy Movement) in attempt to increase students' reading culture in SMAN 1 Geger, Madiun regency. Based on the discussed problems, this research used descriptive qualitative research. The research subjects were vice principal in charge of facilities and infrastructure, literacy team, staffs, librarian and two students of class XI (a girl and a boy). Data were collected through interview, field observation and documentation. The data collected were, then analyzed by using interactive model. Based on the analyzed data, it can be concluded that the School Literacy Movement has been concretely realized and done. Several parties, who have important roles in the literacy movement, gradually show their concerns. The GLS activity is done every morning before the class starts. There is a reading journal book provided in each classroom, to monitor the students' development of doing literacy activity.
\end{abstract}

Keywords: Literacy; Reading Culture

\section{Pendahuluan}

Dalam PIRLS 2011 International Results in Reading, Indonesia menduduki peringkat ke-45 dari 48 negara peserta dengan skor 428 dari skor rata-rata 500 (IEA, 2012). Sementara itu, uji literasi membaca dalam PISA 2009 menunjukkan peserta didik 
Indonesia berada pada peringkat ke-57 dengan skor 396 (skor rata-rata OECD 493), sedangkan PISA 2012 menunjukkan peserta didik Indonesia berada pada peringkat ke64 dengan skor 396 (skor rata- rata OECD 496) (OECD, 2013). Sebanyak 65 negara berpartisipasi dalam PISA 2009 dan 2012. Data PIRLS dan PISA, khususnya dalam keterampilan memahami bacaan, menunjukkan bahwa kompetensi peserta didik Indonesia tergolong rendah (Ansyori, 2016).

Untuk itu sekolah sebagai organisasi pembelajaran, Kementerian Pendidikan dan Kebudayaan mengembangkan Gerakan Literasi Sekolah (GLS). GLS adalah upaya menyeluruh yang melibatkan semua warga sekolah (guru, peserta didik, orang tua/wali murid) dan masyarakat, sebagai bagian dari ekosistem pendidikan. Mereka diharapkan dapat menjadi pendorong keberhasilan gerakan ini. Seiring dengan hal yang diungkapakan di atas, ternyata masyarakat Indonesia juga memiliki minat baca yang sangat rendah, bahkan membaca tidak terlalu popular di kalangan masyarakat Indonesia (Ansyori, 2016: 1).

Konsep literasi sebagai memahami dan memahamkan melahirkan istilah literasiproduktif dan literasi-reseptif. Konsep ini merujuk pada upaya memahami melalui aktivitas berbahasa pasif (membaca, menyimak), dan upaya memahamkan melalui aktivitas berbahasa aktif (menulis, berbicara). Dengan demikian literasi produktif dibatasi maknanya sebagai proses transfer informasi melaui keterampilam menulis yang mampu memahamkan melalui pemanfaatan teknologi

Bertolak dari fenomena di atas GLS sebagai salah satu upaya untuk meningkatkan minat baca anak yang merupakan cikal bakal budaya baca, cukup menarik untuk diteliti. GLS belum lama dicanangkan oleh pemerintah sebagai gerakan nasional di sekolah-sekolah. Di wilayah selatan Kabupaten Madiun, GLS merupakan produk baru dari pemerintah yang baru satu sekolah mengimplementasikan gerakan tersebut pada awal tahun pelajaran 2016-2017 tingkat sekolah menengah atas. Sehingga peneliti tertarik melakukan penelitian ini dalam usaha untuk mengetahui implementasi Gerakan Literasi Sekolah dalam meningkatkan budaya baca di SMA Negeri 1 Geger, Kabupaten Madiun.

\section{Metode Penelitian}

Penelitian ini menggunakan deskriptif kualitatif. Penelitian deskriptif kualitatif adalah mengarah pada pendeskripsian secara rinci dan mendalam mengenai potret kondisi tentang apa yang sebenarnya terjadi di lapangan studinya. Penelitian ini memberikan deskripsi mengenai implementasi Gerakan Literasi Sekolah dalam meningkatkan budaya baca.

Lokasi Penelitian ini dilaksanakan di SMA Negeri 1 Geger, Kabupaten Madiun. Waktu penelitian dimulai pada bulan Agustus 2016 sebagai observasi awal dan selesai pada bulan Agustus 2017. Sumber data dalam penelitian ini meliputi informan (narasumber), peristiwa, serta dokumen atau arsip. Teknik pengumpulan data yang digunakan yakni wawancara, observasi, dan mengkaji dukumen. Penelitian ini menggunakan teknik Trianggulasi dengan sumber. Teknik analisis data yang digunakan dalam penelitian ini adalah menggunakan analisis data yang dilakukan secara interaktif. Interaksi selanjutnya dilakukan antarkomponen, analisisnya meliputi reduksi data, sajian data, penarikan simpulan dan verifikasi. 


\section{Hasil dan Pembahasan}

Gerakan Literasi Sekolah merupakan gebrakan baru untuk membangkitkan semangat literasi di sekolah-sekolah, terutama sekolah-sekolah yang berada di daerah. Pradana (2017) Ada beberapa kendala yang dihadapi sekolah, pertama yaitu, kendala dalam kaitannya dengan dana yang disediakan. Karena dana yang disediakan tidak mencukupi, akhirnya pihak sekolah membatasi program ataupun pengadaan sarana dan prasarana yang sebelumnya sudah direncanakan. Dalam pendidikan formal, peran aktif para pemangku kepentingan, yaitu kepala sekolah, guru sebagai pendidik, tenaga kependidikan, dan pustakawan sangat berpengaruh untuk memfasilitasi pengembangan komponen literasi peserta didik. Agar lingkungan literasi tercipta diperlukan perubahan paradigma semua pemangku kepentingan. Hal inilah yang perlu dikembangkan terkait kesiapan pemangku kepentingan dalam menyukseskan GLS tersebut (Rahayu, 2016).

Pengimplementasian Gerakan Literasi Sekolah yang diawali tahun pelajaran ini, tahun 2016-2017, melibatkan semua elemen yang berada di sekolah maupun di masyarakat. Gerakan ini belum lama dicanangkan oleh pemerintah sebagai gerakan nasional di sekolah-sekolah, sehingga belum banyak sekolah yang menerapkannya sebagai gerakan yang harus diterapkan tahun pelajaran 2016-2017 ini. Sedangkan di wilayah selatan daerah kabupaten Madiun ini, baru satu sekolah yang mengimplementasikan gerakan ini, setingkat SMA. Hal ini berbarengan dengan dicanangkannya sekolah tersebut sebagai sekolah rujukan kurikulum 2013 di kabupaten Madiun.

Hal ini seperti yang diharapakan oleh Kementerian Pendidikan dan Kebudayaan, untuk mengembangkan sekolah sebagai organisasi pembelajaran maka dicanangkanlah Gerakan Literasi Sekolah (GLS). GLS adalah upaya menyeluruh yang melibatkan semua warga sekolah dan masyarakat, untuk menjadi pendorong keberhasilan gerakan ini (Ansyori, 2016: 1).

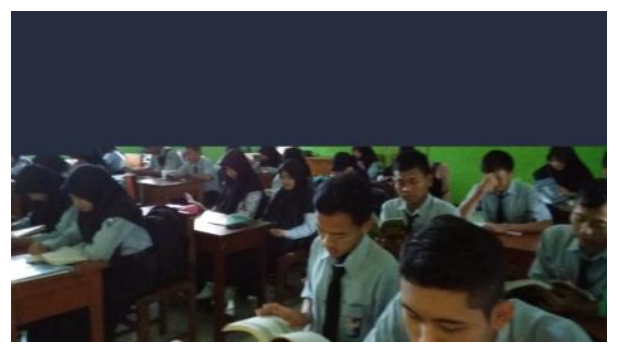

Gambar 1. Kondisi Saat Literasi di Kelas

Dalam pelaksanaan di lapangan, Gerakan Literasi Sekolah ini telah terprogam dengan baik seiring dengan Program Pengembangan Sekolah. Gerakan Literasi Sekolah sangat membantu Program Pengembangan Sekolah yang menekankan pada pemanfaatan IT dalam pembelajaran dan meningkatkan kembali adiwiyata. Pada dasarnya Kegiatan Literasi Sekolah atau GLS sangat menunjang Program-program Pengembangan Sekolah, karena dengan literasi siswa lebih terlatih memahami buku atau bacaan yang mereka baca.

Prosedur pelaksanaan Gerakan Literasi Sekolah diawali dengan pembentukan Tim Literasi. Selanjutnya Tim Literasi yang melakukan dan memantau pelaksanaan GLS di lapangan. Perencanaan kegiatan ini dikoordinasikan terlebih dahulu dengan pihak terkait yang memiliki wewenang mengatur jadwal dan sarana prasarana kegaiatan belajar mengajar di sekolah, seperti wakil kepala sekolah kurikulum, wakil kepala 
sekolah sarana prasarana, dan tenaga pendidik, agar pelaksanaan literasi tidak mengganggu jam KBM. Dengan pelaksanaan literasi yang dilakukan di awal masuk sebelum jam pertama mulai diharapkan pembelajaran tidak akan terganggu.

Sebelum Gerakan Literasi Sekolah ini dimulai, diadakan sosialisasi pada bapak ibu guru dan para siswa. Para siswa membawa buku dari rumah untuk bahan literasi. Buku tersebut dapat berupa novel, cerpen atau buku ilmu pengetahuan umum, bukan buku pelajaran.

Pelaksanaan GLS lima belas menit sebelum jam pertama KBM dimulai. Setiap hari setelah bel masuk berbunyi, para siswa melakukan kegiatan berdo'a bersama di kelas masing-masing. Setelah berdo'a bersama yang dipimpin oleh kepala sekolah, para siswa menyanyikan lagu kebangsaan Indonesia Raya yang dipandu melalui pengeras suara. Kegiatan hari Senin, setelah serangakaian kegiatan tersebut, para siswa persiapan Upacara Bendera, bila hari Jum'at, kegiatan yang mereka lakukan setelah menyanyikan lagu Indonesia Raya, melantunkan Asmaul Husna. Selain hari Senin dan Jum'at, yaitu hari Selasa, Rabu, Kamis, dan Sabtu, para siswa mengikuti kegiatan literasi selama 15 menit setelah berdo'a dan menyanyikan lagu Indonesia Raya. Jadi meskipun ada kegiatan tambahan GLS di pagi hari sebelum jam pertama dimulai, tidak menghilangkan kegiatan lain yang telah lebih dulu menjadi kegiatan rutin para siswa. Deskripsi ini seperti yang diungkapkan oleh Satrianto et al (2016: 9), kegiatan membaca dalam waktu pendek, namun sering dan berkala lebih efektif daripada satu waktu yang panjang namun jarang (misalnya 1 jam/ minggu pada hari tertentu). Hal tersebut juga diuraikan oleh Ansyori (2016: 1) bahwa salah satu kegiatan di dalam gerakan tersebut adalah "kegiatan 15 menit membaca buku nonpelajaran sebelum waktu belajar dimulai".

Buku Jurnal Baca disediakan di setiap kelas, untuk memantau perkembangan siswa dalam kegiatan literasi. Setiap selesai membaca, para siswa mencatat judul buku, pengarangnya atau penulisnya dan ringkasan ceritanya dalam buku jurnal tersebut. Dari buku jurnal tersebut akan terlihat siswa yang rajin membaca dan yang tidak. Jurnal membaca merupakan alat untuk memantau hasil dari literasi yang dilakukan oleh siswa. Hal ini seperti yang diungkap oleh Satrianto et al (2016: 9), bahwa jurnal membaca harian membantu peserta didik dan guru untuk memantau jenis dan jumlah buku yang dibaca untuk kegiatan membaca 15 menit, terutama membaca dalam hati.

Dalam kegiatan literasi atau GLS ini, para siswa membawa buku dari rumah. Jenis buku yang mereka bawa beragam sesuai kegemarannya antara lain; novel, cerpen, majalah, komik, buku pengetahuan umum dan lain-lain. Setelah selesai membaca satu buku yang dibawa, siswa dapat meminjam buku temannya bila berminat, dan hal ini dapat dilakukan secara bergiliran atau bergantian, saling menukar buku bacaan. Kondisi di atas sesuai dengan prinsip-prinsip literasi dalam tahap pembiasaan, antara lain peserta didik dapat diminta membawa bukunya sendiri dari rumah dan buku yang dibaca adalah pilihan peserta didik sesuai minat dan kesenangannya, Satrianto et al (2016: 9).

GLS atau literasi dapat meningkatnya daya baca siswa terhadap teks yang dibaca, membuat mereka suka membaca. Hal ini dapat dilihat di lapangan, saat literasi berlangsung di setiap kelas tampak hening. Para siswa sedang asyik membaca atau sedang menikmati buku bacaan yang dibawa dari rumah. Mereka selalu menandai bagian akhir yang dibaca pada bukunya. Kegemaran membaca pada diri siswa mulai terlihat saat bel pertama sebagai tanda dimulainya pembelajaran atau KBM berbunyi,

Linguista Vol. 1, No. 2, Desember 2017: $55-62$ 
beberapa dari siswa tampak enggan meletakkan buku bacaannya. Hal tersebut juga berpengaruh pada perbincangan siswa dengan teman-temannya, kadang dari mereka sangat semangat bercerita tentang sosok atau tokoh dalam buku cerita mereka. Gambaran ini seiring dengan tujuan kegiatan literasi yang dilaksanakan, yaitu untuk menumbuhkan minat baca peserta didik serta meningkatkan keterampilan membaca agar pengetahuan dapat dikuasai secara lebih baik. Materi baca berisi nilai-nilai budi pekerti, berupa kearifan lokal, nasional, dan global yang disampaikan sesuai tahap perkembangan peserta didik (Ansyori, 2016: 1).

Dalam kegiatan literasi atau GLS ini, jenis buku yang dibawa dari rumah oleh para siswa beragam, antara lain; novel, cerpen, majalah, komik, buku pengetahuan umum dan lain-lain. Keanekaragaman jenis buku yang dibawa para siswa membuat warna tersendiri dalam kegiatan literasi di sekolah, sehingga para siswa dapat membawa buku bacaan kegemarannya. Ketertarikan siswa pada buku yang dibawa membuat mereka selalu penasaran dengan kelanjutan cerita atau isi buku tersebut. Setelah selesai membaca satu buku yang dibawa, siswa dapat meminjam buku temannya bila berminat, dan hal ini dapat dilakukan secara bergiliran atau bergantian, saling menukar buku bacaan. Kondisi di atas sesuai dengan prinsip-prinsip literasi dalam tahap pembiasaan, antara lain peserta didik dapat diminta membawa bukunya sendiri dari rumah dan buku yang dibaca adalah pilihan peserta didik sesuai minat dan kesenangannya, Satrianto et al (2016: 9).

Dengan deskripsi tersebut jelas budaya baca sudah mulai terlihat, meskipun belum menyeluruh. Hal ini seperti yang digambarkan oleh Sutarno (2006: 27), bahwa budaya baca adalah suatu sikap dan tindakan atau perbuatan untuk membaca yang dilakukan secara teratur dan berkelanjutan. Seorang yang mempunyai budaya baca bila orang tersebut telah terbiasa dan berproses dalam waktu yang lama selalu menggunakan sebagian waktunya untuk membaca. Dan salah satu fungsi membaca sebagai fungsi rekreatif telah dapat dirasakan beberapa siswa, jadi tidak hanya sekedar membaca karena tuntutan dalam kegiatan literasi. Hal ini seiring dengan yang disampaikan Mulyono (2013: 39), bahwa membaca dapat digunakan sebagai upaya menghibur hati, mengadakan tamasya yang mengasyikkan, dengan membaca bacaanbacaan ringan, novel-novel pop, cerita humor, fable, karya sastra, dan lain-lain.

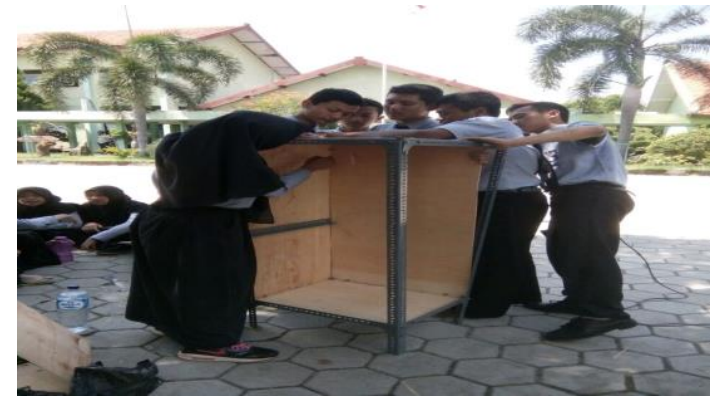
Gambar 2. Saat para siswa mendesain sendiri rak buku yang akan diletakkan
di pojok kelas

Selain membawa buku sendiri dari rumah, siswa juga diberi pilihan untuk membaca buku yang disediakan oleh perpustakaan mini di masing-masing kelas. Keberadaan perpustakaan mini yang merupakan karya siswa sendiri dan hasil dari kreasi satu kelas, membuat beberapa siswa terbantu untuk memperkaya buku bacaan 
mereka saat literasi, tanpa membelinya. Deskripsi ini seirama dengan salah satu indikator yang digunakan untuk rujukan ketercapaian literasi pada tahap pembiasaan, yaitu terdapat perpustakaan, sudut baca di tiap kelas, dan area baca yang nyaman dengan koleksi buku nonpelajaran, Satrianto et al (2016: 9).

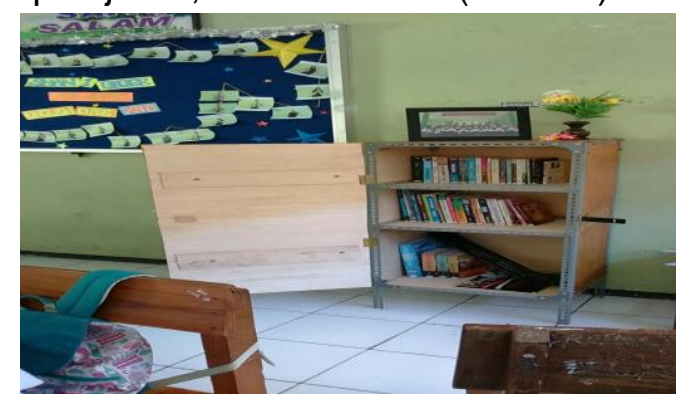

Gambar 2. Perpustakaan mini yang terdapat di setiap kelas

Mengubah sebuah budaya tidak semudah membalikkan tangan, perlu sebuah gerakan yang menyeluruh dan didukung oleh semua pihak yang terkait. Latar belakang sosial dan budaya masyarakat kita memang sangat berpengaruh pada kesuksesan gerakan ini. Peserta didik atau siswa yang semula memang telah menyukai membaca, dengan mudah beradaptasi dengan kegiatan literasi yang dikemas dalam GLS ini. Tetapi bagi siswa yang awalnya tidak suka membaca, mengalami kesulitan untuk mengadopsi kegiatan literasi ini. Meskipun dilakukan hanya 15 menit selama 4 hari dalam 1 minggu, sikap malas dan enggan jelas terlihat.

Gambaran tersebut senada dengan yang diutarakan oleh Haryanti (2014: 1). Bahwa membudayakan atau membiasakan untuk membaca, apalagi menulis perlu proses, jika dalam suatu kelompok masyarakat kebiasaan tersebut memang belum ada atau belum terbentuk. Kegiatan literasi merupakan kegiatan berbahasa, Sehingga situasi sosial dan budaya sangat berpengaruh pada keberhasilannya (Septiani, 2014: 1). Dan peserta didik atau siswa tetaplah anak-anak, meskipun kadang terlihat dewasa, mereka harus selalu dibimbing dan diawasi (Ansyori, 2016:1). Jadi semua elemen yang diharapakan oleh pemerintah untuk keberhasilan kegiatan literasi ini, bekerja sama membiasakan diri untuk membaca, yang muara akhinya nanti terciptalah budaya baru, yaitu budaya baca.

Perbedaan jenis kelamin berpengaruh pada kegemaran peserta didik, terutama kegemaran pada jenis bacaan. Hal ini sangat berpengaruh dalam kegiatan literasi. Peserta didik yang perempuan cenderung menikmati bacaan yang dibacanya, sementara peserta didik yang laki-laki aktif melakukan hal yang lain, sealain membaca. Keterbatasan jenis bacaan yang mereka miliki dan yang terdapat di perpustakaan, baik perpustakaan mini maupun perpustakaan sekolah, membuat siswa laki-laki tidak bersemangat menyambut kegiatan baru di tiap pagi hari ini. Sementara jenis bacaan yang banyak dijumpai adalah bacaan fiksi, yang cenderung lebih disukai oleh siswa kaum hawa.

Kenyataan di atas sesuai dengan yang diungkapkan dalam beberapa penelitian bahwa laki-laki lebih memilih untuk membaca informasi-informasi faktual daripada cerita dan hanya mencari informasi tertentu yang diinginkannya daripada membaca dari awal sampai akhir. Hal tersebut dibenarkan oleh Sugiarto (2007: 9), bahwa kemampuan linguistik perempuan berkembang lebih dahulu dan lebih baik jika dibandingkan dengan 
laki-laki. Dengan kata lain, pendapat ini dapat dikatakan bahwa kemampuan membaca siswa laki-laki dan siswa perempuan memang berbeda.

Sementara keberadaan perpustakaan di sekolah juga tidak dapat membantu teratasinya kendala yang diungkapkan di atas. Hal tersebut sesuai dengan yang disampaikan oleh Trini Haryanti (2011: 3), bahwa beberapa faktor penghambat peningkatan minat baca dalam masyarakat dewasa ini, antara lain langkanya keberadaan buku-buku anak yang menarik terbitan dalam negeri, dan kurang tersedianya taman-taman bacaan yang gratis dengan koleksi buku yang lengkap dan menarik.

Hal di atas diperburuk lagi dengan para guru atau tenaga pendidik, siswa dan orang tua yang seharusnya seiya sekata untuk melaksanakan gerakan literasi ini dengan rasa tanggung jawab. Tetapi pada kenyataannya, beberapa elemen tadi tidak mendukung kegiatan literasi ini. Berdasarkan pengamatan langsung, salah satu kendala dari beberapa kendala yang lainnya adalah kurangnya pengawasan pelaksanaan literasi oleh bapak ibu guru pengajar pada jam pertama, sebab pengawasan literasi di kelas sepenuhnya tanggung jawab bapak ibu guru pengajar pada jam pertama. Kurangnya pengawasan tersebut berakibat pada perlakuan siswa terhadap program ini. Seperti yang diungkapkan oleh Ansyori (2016: 1), bahwa GLS adalah upaya menyeluruh yang melibatkan semua warga sekolah, yaitu guru, siswa, orang tua/wali murid, yang merupakan bagian dari ekosistem pendidikan. Mereka diharapkan dapat menjadi pendorong keberhasilan gerakan ini. Sebagai bagian dari ekosistem pendidikan, peran mereka menjadi sangat penting. Merekalah penggerak dalam kegiatan ini. Kerja sama semua elemen tersebut sangat diperlukan untuk melaksanakan gerakan bersama yang terintegrasi dan efektif.

\section{Kesimpulan}

Pengimplementasian Gerakan Literasi Sekolah sudah mulai menunjukkan gaungnya, meskipun belum sepenuhnya sesuai dengan harapan pemerintah. Pelaksanaan GLS di lapangan, dilakukan pada pagi hari sebelum jam pertama atau sebelum memulai KBM. Beberapa pihak yang merupakan komponen penting dari gerakan literasi ini, secara pelan tetapi pasti mulai menunujukkan kepeduliannya. Pelaksanaan GLS di lapangan, dilakukan pada pagi hari sebelum jam pertama atau sebelum memulai KBM. Pelaksanaan gerakan literasi ini, tidak dilakukan setiap hari, tetapi hari-hari tertentu, seperti 4 hari dalam seminggu.

Buku Jurnal Baca disediakan di setiap kelas, untuk memantau perkembangan siswa dalam kegiatan literasi. Dari buku jurnal tersebut kegiatan literasi dapat dipantau perkembangannya, sebab akan terlihat siswa yang rajin membaca dan yang tidak. Buku Jurnal Baca disediakan di setiap kelas, untuk memantau perkembangan siswa dalam kegiatan literasi. Tujuan GLS atau literasi untuk menciptakan dan meningkatkan budaya baca, sudah mulai terasa. Kegemaran membaca pada diri siswa mulai terlihat, meskipun belum menyeluruh.

Ditemukan banyak kendala dalam kegiatan literasi atau GLS ini, antara lain: Kendala dari bebepa warga sekolah yang seharusnya mendukung gerakan literasi ini, tetapi pada kenyataannya banyak yang masih belum menyadari tanggung jawabnya. Kendala berikutnya dari peserta didik yang memiliki latar sosial budaya yang jauh dari budaya literasi, dan hal ini juga dipengaruhi oleh jenis kelamin yang membedakan 
kegemaran peserta didik terhadap jenis bacaan, yang pada akhirnya berpengaruh pada kegiatan literasi tersebut. Kendala terakhir dari unsur penunjang keberhasilan program pemerintah ini, yaitu keberadaan perpustakaan di sekolah. Perpustakaan yang terdapat di sekolah pada umumnya belum lengkap menyediakan banyak pilihan untuk bahan bacaan peserta didik, sehingga siswa yang tidak mendapatkan jenis buku yang diinginkan menjadi enggan untuk berliterasi.

Mengingat pentingnya Gerakan Literasi Sekolah ini, Semua elemen sekolah sebaiknya bersatu padu untuk ikut aktif dalam menyukseskan program literasi atau GLS ini. Tanpa contoh dari sosok yang pantas menjadi panutan, siswa juga akan bertindak yang sama.

\section{Daftar Pustaka}

Ansyori, H. R. (2016). "Menumbuhkan Minat Baca Sebagai Upaya Meningkatkan Kualitas Sumber Daya Manusia". http://imadiklus.com/menumbuhkan-minatbaca-sebagai-upaya-meningkatkan-kualitas-sumber-daya-manusia/. Diunduh tanggal 8 September 2016

Haryanti, T. (2011). Meningkatkan Budaya Baca. http://www.triniharyanti.id/2011/09/meningkatkan-budaya-baca.html. Diunduh tanggal 16 September 2016

Hairul, M. (2017). LITERASI PRODUKTIF BERBASIS IT (Mencipta Aplikasi Berbahasa Indonesia Pembawa Pengetahuan). FKIP e-PROCEEDING, 187-196.

Mulyono. (2013). Problematika Pembelajaran Membaca Puisi Pada Siswa Kelas XII Teknik Komputer Dan Jaringan (TKJ) Semester I SMK Negeri 1 Jiwan Kecamatan Jiwan Kabupaten Madiun Tahun Pelajaran 2012/2013. Madiun: Universitas PGRI.

Pradana, B. H., Fatimah, N., \& Rochana, T. (2017). Pelaksanaan Gerakan Literasi Sekolah Sebagai Upaya Membentuk Habitus Literasi Siswa Di Sma Negeri 4 Magelang. Solidarity: Journal of Education, Society and Culture, 6(2), 167-179.

Rahayu, T. (2016). Penumbuhan Budi Pekerti Melalui Gerakan Literasi Sekolah.

ST, Septiani. (2014). BAB II Kajian Teoretis Tentang Literasi. .http://repository.usu.ac.id/bitstream/123456789/41772/4/Chapter\%20ll.pdf. Diunduh tanggal 8 September 2016

Sutrianto, dkk. (2016). Panduan Gerakan Literasi Sekolah di Sekolah Menengah Atas. Jakarta: Direktorat Jenderal Pendidikan Dasar dan Menengah Kementerian Pendidikan dan Kebudayaan.

Sugiarto. (2007). Perbedaan Hasil Membaca Antara Siswa Laki-laki dan Perempuan yang Diajar Dengan Menggunakan Teknik Skimming. http://infosiswa.blogspot.co.id/2007/06/perbedaan-hasil-belajar-membacaantara.html.Diunduh tanggal 12 Agustus 2017 